\title{
THE BLENDED FESTIVALSCAPE AND ITS SUSTAINABILITY AT NONURBAN FESTIVALS
}

\author{
DAVID GRATION, ${ }^{*} \uparrow$ CHARLES ARCODIA, ${ }^{*}$ MARIA RACITI, $\uparrow$ and ROBYN STOKES* \\ *School of Tourism, University of Queensland, Australia \\ $\uparrow$ Faculty of Business, University of the Sunshine Coast, Australia
}

\begin{abstract}
This article identifies the major elements of festivalscapes at nonurban festivals and their implications for sustainable site management by event organizers. While research on the need to maintain and reinvigorate the servicescapes of retail precincts (e.g., shopping malls) and hotels is well documented, the same cannot be said of event venues and sites. There is a notable absence of research that explores how nonurban festival sites can maintain their unique natural environment attributes while sustaining consumer interest through incremental changes in the overall festivalscape. Two Australian festivals, Woodford Folk Festival (Woodford, Queensland) and the National Country Music Muster (Gympie, Queensland), are used in this article to illustrate the need for management intervention to create blended festivalscapes that achieve environmental, social, and economic goals-a Triple Bottom Line (TBL) measure of success.
\end{abstract}

Key words: Servicescape; Blended festivalscape; Nonurban; Festival; Triple bottom line; Sustainability

\section{Introduction}

In an increasingly pressurized world, many consumers seek a hedonic escape, be it in the form of a nostalgic return to better times and better places retroscapes (Brown \& Sherry, 2003) or an idealized place. Writers in the field of consumer behavior refer to consumers desire for an escape to an idealized social-servicescape (Tombs \& McColl-Kennedy, 2003) or "third place" such as a regularly visited coffee shop (Rosenbaum, 2006) in which they can have for a short period of time a place that is other than the usual experience. In this context, fes- tivals and events also provide a hedonic escape for consumers. Indeed, Petrick and Li (2006) note that the past few decades have established festivals and events as one of the fastest growing sectors in the world leisure industry. Growth in festivals in nonurban settings has led to a need for greater research into how such events may be managed and evaluated.

Recently, Gibson and Stewart (2009) identified 2,856 regional festivals in just three Australian states, generating over \$AUD10 billion in local economic activity. A key element in satisfying consumer demand for these regional festivals, and ensuring their sustainability, is the experiential setting in 
which these events are delivered. These "blended festivalscapes," incorporate the atmosphere of the general service encounter derived from a blend of built, natural, and staged components that together create a sense of communitas for consumers (Getz, 2007; Lee, Lee, Lee, \& Babin, 2008; M. Morgan, 2008, Turner, 1974). In this context consumers may perceive the positive/approach aspects of "natural" environments to include man-made settings and staged authenticity, such as artificial lakes and gardens (Ulrich, 1993). Australian self-image like that of many other countries is grounded in landscape related imagery. Americans have the folklore of the "West," the English have the romantic rural idyll, and Australians have the "Bush" with its images of wild natural areas and bushrangers (Robin Hood style characters). "The meaning behind these images not only reflects the attitudes and political environment of the day, but also can influence potential tourists desires to visit the country" (Beeton, 2004, p. 125). According to the seminal work of Fullerton (1928) "All of Australia that is not city, town, or suburb, is loosely referred to as 'the bush' by most people. In its narrower and more correct meaning it ... is used to mean the actual timber and scrub country" (p. 36).

This article investigates and further defines the concept of festivalscapes and ways in which the Triple Bottom Line (TBL) framework can serve as a reference point in interpreting consumer perspectives about the overall festivalscape. Observations arising from the study which also include the perspectives of festival managers can contribute to further refinements of the TBL framework as it applies to festivals and in turn, the quest to optimize the sustainability of the holistic or blended festivalscape. In seeking to fulfill these aims, the research acknowledges and addresses Bitner's observation (1992) that "managers continually plan, build, and change an organizations physical surroundings in an attempt to influence its patrons, without really knowing the impact of a specific design or atmospheric change on it users" (p. 57).

\section{The Role of Festivalscapes and "Scapes"}

\section{Festivalscapes}

Lee et al. (2008) have suggested that a "festivalscape" describes the general atmosphere experienced by festival patrons and related emotional responses that are tied to perceived festival quality, satisfaction, and loyalty responses. The festivalscape concept draws principally on Bitner's (1992) seminal work on servicescapes. Yet Bitner's conceptual framework that encompasses ambient conditions, special layout and signs, symbols and artifacts, fails to incorporate the people related elements of the "scape." Lee et al. (2008) identified seven dimensions that may impact consumer satisfactionprogram content, staff service, facilities, food, souvenirs, convenience, and information availability. These dimensions underline the importance of intangible elements in shaping the hedonic experiences sought by festival-goers. A further omission from Bitner's (1992) servicescapes, not addressed in Lee and colleagues' (2008) festivalscapes, is the natural environment, which is a vital part of the total scape in many festival contexts. To pave the way for a more comprehensive model of festivalscapes, this article explores a number of perspectives, including the interface of people with scapes, the impact of atmospherics, and the endowment of meaning on physical scapes to create a sense of place. Ultimately, the authors examine consumer perspectives of two case festivals through the lens of a TBL servicescape and ways in which the festivals involved account for social, environmental, and economic dimensions.

\section{Scapes and People}

According to the seminal work of Aldrich (1966) the term scape derives from landscape and refers to a specific view of scenery. However, over time scape has become a common ending attached to many words other than land. Accordingly, scape today can be seen as a framework within which a scene can be viewed and the populated scape is increasingly relevant.

During the 1970s, work began in earnest on exploring the interactions between people and environment with social researchers such as Bennett and Bennett (1970) asserting that "all social interaction is affected by the physical container in which it occurs" (p. 22). Mehrabian and Russell (1974). who focused on environmental stimuli and resulting impacts on consumers, established the wellsupported (Donovan \& Rossiter, 1982; Ezeh \& Harris, 2007; Newman, 2007; Parasuraman, Zeithaml, \& Berry, 1985) Stimulus-Organism-Response 
model (SOR) in which environmental stimuli lead to emotional states that in turn produce an approach/ avoidance response. Ulrich $(1983,1986)$ suggests that affective responses, such as aesthetic preference, directly impact on a landscape observer's thoughts, conscious experience, and behavior. U1rich (1993) further proposes humankind has evolved to have "various responses - both positive/approach (biophilic) responses and negative/avoidance (biophobic) responses - to certain natural stimuli and configurations" (p. 75). Blended festivalscapes can therefore be seen as having a critical impact on festival consumers and ultimately, their purchase and repurchase intentions.

\section{Service Encounter Atmospherics}

While earlier research concentrated on the social aspects of "people-environment" relationships, Kotler (1973) introduced a marketing viewpoint, identifying how service encounter atmospherics can be created through the manipulation of environmental cues. Kotler's Atmospherics, with its framework of visual, aural, olfactory, and visual staged environmental impacts, effectively set the scene for later research by Belk (1975), Shostack (1977), and the seminal work of Bitner (1992). Kotler's (1973) framework encompassed ambient conditions, special layout and signs, symbols, and artifacts, but it failed to incorporate the nontangible people related elements of the scape or the fixed parts of the natural environment. This initial work on closed "laboratory style" service environments, where all elements are controllable, became a primary research context. While various components of the physical environment are said to jointly affect individuals' behaviors and responses (Holahan, 1982), most studies have concentrated on single or restricted servicescape cues, such as music or color (Lin, 2004; Mattila \& Enz, 2002) rather than a holistic approach to the service environment. In effect, a compromise on the boundaries of scope has been evident among researchers (e.g., Wakefield \& Blodgett, 1996) who have limited their framework to servicescape elements that are more directly within managerial control. This constrained research focus tends to narrow our understanding of the total impact of the blended festivalscape in which natural and built dimensions coexist and impact upon festival consumers.

\section{Blended Servicescapes (Natural and Built)}

There has been a paucity of research addressing the holistic or blended servicescape. Examples of relevant research include Arnould and Price (1993) who investigated the relationship of commercial activities to a natural riverscape setting, and Clarke and Schmidt (1995) who focused on natural and artificial service encounters at an historical property in a national park. Arnould and colleagues (1998) and Curtin (2010) also examined communicative staging of commercial activities in a wilderness setting while Slatten and colleagues (2009) investigated the importance of design and ambience in the hedonic servicescape of a Winter Park in Norway. Irrespective of the setting, the common thread in the research findings is encapsulated by Clarke and Schmidt's (1995) statement "where a service encounter coexists with an environmental encounter, there will be, in most cases, a symbiotic relationship between the two" (p. 161).

In general, blended servicescape research has been heavily influenced by earlier anthropological place researchers (Relph, 1976; Tuan, 1974, 1977). These researchers produced a number of seminal works on the meaning of place and a person's sense of place. Tuan (1974) and later Relph (1976) addressed the affective (emotional) bond between people and place, drawing attention to different perspectives towards the same place among locals and visitors. Space is perceived as a simple geographic/physical reality. In order to become a place, we need to endow it with meaning through either direct or indirect experience. For most of us, place conjures up memories and emotions which can influence behavior (Relph, 1976; Tuan, 1977). One such place is the winescape (Getz, 2000; McDonnell \& Hall, 2008; Taylor \& Shanka, 2002) in the wine tourism domain where both natural and built environments impact on consumers. Here, the primary focus has been on the "cellar door" servicescape and its experiential components.

In retail settings, the different elements of internal and external scapes have each been viewed as influential (Berman \& Evans,1995; Donnovan \& Rossiter, 1982), furthering the atmospherics through physical evidence such as the condition and style of the store exterior, the general interior, lighting, point-of-purchase, and decorations. The move to include external components of the servicescape, 
such as constructed gardens and exterior signage, has also been widely accepted (Berman \& Evans, 1995). Nonetheless, minimal research has incorporated the natural environment elements of the servicescape. Kwortnik's (2008) article on cruise lines puts forward the concept of shipscapes, where the social and man-made environments of the ship blend with the natural environment of the ocean to create an overall positive cruise experience. However, in general, research of blended servicescapes that account for social, economic, and environmental realms are notably absent. Thus, a contribution of this study is the comprehensive TBL evaluation or the creation of a holistic blended festivalscape as a measure of festival success.

\section{Sustainability and the Triple Bottom Line (TBL)}

Prior to considering the concept of sustainability within the festival context, it is valuable to reflect upon seminal interpretations of sustainability. The World Commission on Environment and Development's report to the UN General Assembly, Our Common Future (World Commission on Environment and Development, 1987) defined sustainable development as meeting ".the needs of the present without compromising the ability of future generations to meet their own needs" (para 1). This focus on needs rather than wants and desires, and on future rather than present generations, provides a challenge for modern capitalist societies with their systems of responsibility to shareholders.

This concept of individuals and communities using their resources wisely in order to allow for future activities by subsequent generations is not a new concept. Many cultures have pursued sustainable practices, in areas such as food gathering and growing, in an effort to improve their chances of survival. In contrast, communities with an abundance of natural resources have tended to be more profligate in their management of those resources. Therefore, historically, sustainable development can be seen to have been predominantly based on maximizing opportunities, based on accessible resources, rather than any real sense of environmental conservation. Cochrane (2009) illustrates this viewpoint with her statement that "one effect of the crystallization of a picturesque view of the countryside is that the landscape features evolved over the centuries as a practical response to farming or lifestyle needs, such as dry-stone walls or laid hedges, are now considered desirable for aesthetic reasons" (p. 71).

Emerging from the study of social impacts just over a decade ago (Elkington, 1997) the TBL evaluation is now a widely, but not universally (Norman \& MacDonald, 2004), accepted evaluative framework among governments and corporations seeking to assess the balanced environmental, social, and economic outcomes of organizational activities. This heuristic framework relies on businesses acting in a responsible manner to ensure positive outcomes for the environment (Planet), society (People), and its own economic benefit (Profit) based on rational decision making processes (Milne, Kearins, \& Walton, 2006). According to Norman and MacDonald (2004), TBL supporters believe that in a similar manner to the financial bottom line results of organizations that are accessible to stakeholders, they should also be able to access measured, reported, audited, and reported information on the sociocultural and environmental impacts of organizational activities. The methodologies for evaluating financial outcomes in the internal corporate environment are well established and an increasing body of knowledge regarding economic impact on the wider community is also present. However, "sustainability" as a modern concept has been increasingly focused on the environment and to a lesser extent the sociocultural bottom lines of business operations, where less widely agreed measures are to be found (Hubbard, 2009; Norman \& MacDonald, 2004).

In trying to address the growing call for "sustainable business practices," many companies are creating sustainability strategies and are attempting to set a "sustainability" agenda that is acceptable to the majority of stakeholders. An example is that of British Petroleum, who define sustainability (the antithesis of their Gulf of Mexico oil spill experience) as "the capacity to endure as a group: by renewing assets; creating and delivering better products and services that meet the evolving needs of society; attracting successive generations of employees; contributing to a sustainable environment; and retaining the trust and support of our customers, stakeholders, and communities in which they operate" (British Petroleum, 2010). 
In the tourism arena, which includes festivals among its core attractors, researchers such as Timothy (2000) perceive sustainable tourism to be a:

... forward looking form of tourism development and planning that promotes the longterm health of natural and cultural resources, so that they will be maintained as durable, permanent landscapes for generations to come. The concept also accepts that tourism development needs to be economically viable in the long term and must not contribute to the degradation of the sociocultural and natural environments. (p. 21).

As in the wider corporate world tourism industry questions on the interpretation of the concepts surrounding "sustainability" (Dredge \& Whitford, 2010) and how "TBL" approaches can be actualized to support "sustainable practices" are to be found in the tourism literature where "Everybody is calling for sustainable or 'environmentally and socially compatible' tourism, but whenever these demands crop up, it becomes apparent that everybody interprets the concepts differently" (Muller, 1994, p. 131).

TBL has been increasingly used by researchers in the events field (Fredline, Raybould, Jago, \& Deery, 2005; Getz, 2009; Hede, 2008; Jones, 2010; Robertson, Rogers, \& Leask, 2009; Rogers \& Ryan, 2001; Sherwood, 2007; Small, 2007) to evaluate event impacts. According to Jones (2010) it is generally seen that achieving balanced positive outcomes in all spheres will mutually satisfy all stakeholders, while Getz (2009) supports the importance of examining the impacts of all stakeholders. It is unlikely that a "best of all possible worlds" scenario can ever be fully achieved, but many festival managements are striving to create sustainability policies and practices that reflect the TBL framework and meet their stakeholder's expectations. Considerable progress is yet to be made in the development of tools to rigorously apply TBL in ways that satisfy the quest for balance across people, planet, and profit perspectives. However, insights to the more complex perceptions and engagement of festival-goers with festivalscapes can contribute to refining the scaffold of elements included in future TBL planning and evaluation by festivals.

Bonn and colleagues (2007) point out that for all the millions of dollars spent on renovation of ser- vicescapes, there is limited research on consumer acknowledgement of the changes. If sustainable blended festivalscapes are to be created, consumers' perceptions of these scapes and how those perceptions impact on the three spheres of the TBL framework need to be more fully understood. This gap in research relating to consumer acknowledgement of changes to the blended festivalscape forms part of this research. In this article, consumer interpretations of blended festivalscapes are considered in the TBL context with a view to informing both sustainability planning for events (Hede, 2008) and approaches to post festival evaluation. Clearly, the consumer interpretations of festivalscape and related perspectives of festival managers on the use of the TBL framework derived from this study may serve as a preface to later research to further refine festival specific TBL tools.

\section{Research Focus: Blended Festivalscapes and TBL Goals}

Clarke and Schmidt (1995) suggested that service providers should strive to achieve congruence between natural and artificial encounters in order to generate a greater understanding of the interrelationship between the elements involved in what we have termed as the blended festivalscape. In a similar vein, Oakes (2006) states that "the special effect of landscape can only work, indeed, by spatialising the paradoxes of the tourist experience to specific places and spaces and imagined and real geographies" (p. 448). In contrast Kim and Jamal (2007), in their study of a festival, concluded that "the cultural and built artifacts, including costumes, were important only to the extent that these props... facilitated authentic experiences for the serious tourist" (p. 197). These observations reinforce the need for research that explores festival-goers and their relationship to festival place. This study explores the potential value of the TBL framework of people, planet, and profit in creating consumer desirability and sustainability, in a blended festivalscapes context, from both consumer and management perspectives.

Given the importance of festival-goers' perceptions, the questions that are central to our study are: How do festival consumers and managers understand the nature and significance of the blended 
festivalscape" and How these perspectives can contribute to the further refinement of TBL as a planning tool?

\section{Research Method: A Case Study Approach}

Given the scarcity of research studies into festival servicescapes, in which none provided a holistic overview of a blended festivalscape with multiple dimensions, an exploratory qualitative study was chosen to clarify this phenomenon (Zikmund, 2003). The method chosen to fulfill this theorybuilding research was the case study approach. As Yin $(1993,1994)$ notes, qualitative research via a case methodology is appropriate when the phenomenon (e.g., a blended festivalscape) is difficult to define and it is necessary to examine the topic broadly in the first instance. Two nonurban festivals were chosen as cases with an expectation of similar results for predictable reasons (literal replication) as well as some contrasting outcomes for predictable reasons (such as audience or nature of celebration) that provide for theoretical replication (Yin, 1994). This cross-case analysis enables the researcher to examine the contingency of their findings (Carson, Gilmore, Perry, \& Gronhaug 2001).

Within the cases, group engagement with the topic was seen to be most desirable to collect the qualitative data among attendees (Zikmund, 2003). Nominal/Delphi, natural field, and formal group field were inappropriate to satisfy the exploratory nature of this study, thus in-depth focus groups were selected (Hair, Bush, \& Ortinau, 2003). In particular, the loosely structured, interactive, free flowing, and flexible format of the focus group enables participants to discuss their beliefs, anxieties, convictions, and feelings through spontaneous expression and mutual engagement (Greenbaum, 1998). The need to balance the scope of the research with project manageability was a key consideration leading to the decision to utilize a small scale convenience sample. Accordingly, two nonurban festivals were studied in close proximity to the research team, satisfying the aforementioned need for literal and theoretical replication (Yin, 1994). Supplementing the consumer focus groups in this study was a series of in-depth interviews with the festival managers to investigate the TBL concept and its use in creating and managing the blended festival- scape. The participants were considered to be expert in terms of their knowledge of the festival spaces being explored.

\section{Research Context: Nonurban Festivals}

The two nonurban festivals selected were the National Country Music Muster (Muster) and the Woodford Folk Festival (Woodford). Aspects of similarity or literal replication (Yin, 1994) were observed in the choice of these festivals. Both were readily identifiable as hedonic tourism attractions (Hightower, Brady, \& Baker, 2002) and could provide a depth and breadth of consumer motivations for engagement given their widespread appeal and size (Bowen \& Daniels, 2004; Thrane, 2002). However, key differences could also be observed (theoretical replication) in the cultural orientation of the audiences and the unique sense of place shaped by audiences in these festivalscapes. These two festivals on the fringe of major population centers in nonurban settings are now profiled.

The first case, the Woodford Folk Festival, an Australian regional festival that is held over a 6-day period each December/January, moved to its own property near the town of Woodford in Queensland, Australia, in 1994. The ownership of the property was sold to local government in early 2011, with arrangements for the festival to maintain management rights for the site on a 50-year renewable lease at a small fee. On the "Woodfordia" site, farmland is being progressively reclaimed as "environmental parkland." Woodford Folk Festival is a regional festival of music, arts, and performance managed by the not-for-profit Queensland Folk Federation (QFF) and it currently attracts approximately 130,000 attendees per year.

The second case chosen for this study was the National Country Music Festival, an Australian regional festival that is held over a 6-day period each August. With approximately 40,000 tickets sold and 13 venues with accompanying shops, camping, and amenities, the Muster is located on more than 50 hectares of "bush" within the Amamoor Creek State Forest Park, 2 hours' drive north of Brisbane, near the regional town of Gympie in Australia. The festival is managed by the not-for-profit Gympie Apex Club.

Once the two cases were chosen and necessary 
approvals obtained, a semistructured focus group proforma was prepared for implementation among festival attendees (Aaker, Kumar, Day Lawley, \& Stewart, 2007; Creswell, 2003; Zikmund, 2003). In addition, an interview proforma was prepared for use among the festival managers. The principle researcher served as the moderator of the focus groups and the interviewer of managers. For the focus groups, a Moderator's Guide that aligned with the research questions was created. Supporting materials included a Research Project Information Guide (RPIS) and an Interviewee Consent form. Permission was sought and granted from the National Country Music Muster (Muster) and the Woodford Folk Festival (Woodford) to undertake the research in 2008/2009. The focus group questions were evaluated by one research expert and two context (festival management) experts with subsequent modifications made to the instrument. Similarly, the in-depth interview proforma among festival managers was peer reviewed $(N=2)$.

\section{Research Implementation}

Phase 1: Management Interviews. In-depth interviews were firstly conducted with managers within the two festivals on two occasions. The indepth interview format consisted of open ended questions about the history of the festival, how to define the term "place," the development of the festival site, and the relationship of festival consumers to the site. These in-depth interviews were purpose designed to encourage the managers to reflect upon both the festivalscape and ways in which sustainability management and TBL measures were or could be applied. More specifically, managers were asked to describe the place in which the event happens, the integration of natural and built aspects of the festival, and the ways in which TBL was used in festival planning and reporting.

It should be noted that while TBL, both as a term and concept, was used with the in-depth interviews with festival managers who were familiar with this framework as an evaluative tool, it was not used with focus group participants, to avoid narrowing their prospective range of responses.

Phase 2: Festival-goer Focus Groups. Following the management interviews, a second phase of data collection involved focus groups with festival consumers. Participants were recruited from festival-goers and as such samples tend to generate productive discussions and rich data (D. L. Morgan, 1997). Timing of the focus groups was set in line with the availability of participants and the requirements of the festivals involved. As a result, different methods were employed for the focus groups at the two festivals - one during a festival and one after a festival. Decisions relating to timing and availability then resulted in the selection of a combination of geographic interview sites, these being a festival site (Woodford Folk Festival) and a home region of festival-goers (National Country Music Muster- Nambour, 1 hour's drive from the festival site).

For the Woodford Folk Festival, four semistructured focus groups were scheduled at the festival site, one per day over a 4-day period, with a maximum of eight participants per focus group (Aaker et al., 2007). The focus groups were held under a large shady tree to create a relaxed "festival-like" atmosphere near the middle of the festival site and were timed to minimize impact on the enjoyment of festival programs (Creswell, 2003; Zikmund, 2003). Invitations to participate were posted on official festival notice boards throughout the site, attracting a total of 8 participants with a further 15 participants agreeing to contribute following a direct intercept approach to passersby, at the festival interview site, explaining the focus group purpose and inviting them to take part, during the 10 minutes prior to each focus group. The total number of participants was 23 . While the size of this sample is limited relative to the overall festival population, it did reach theoretical saturation and fulfill its purpose of establishing a conceptual framework of themes for later investigation by the researchers. A priority of the researchers was not to overextend the willingness of festival-goers, as many had already participated in a larger generic festival survey. All focus groups were of no more than 1 hour's duration.

For the National Country Music Muster, one semistructured focus group was scheduled 3 months after the event in Nambour, a township that is approximately 1 hour's drive from the festival site, and a region which had a large number of festivalgoers voluntarily listed on the "Muster Newsletter" email database of the festival management. The fo- 
cus group was held in an arts café in a known country music centre to create a relaxed "festival-like" atmosphere (Creswell, 2003; Zikmund, 2003). Invitations to participate were emailed to past attendees from the Nambour region by the Muster management utilizing their newsletter database. A total of 8 positive responses were received however only 5 participants $(n=5)$ were present at the arranged time. Although small in number, this group was particularly well informed or "expert" in their knowledge of the festival, and provided a very rich depth of perspectives in a focus group of somewhat longer duration (approximately 1.5 hours). The willingness of the 5 focus group participants to engage in a lively discussion supports Fern's (1982) proposition that "if the task is to learn more about consumers' experiences in using products then size (of the focus group) may not be a critical factor" (p. 449). This is further supported by Onweuegbuzie, Dickinson, Leech and Zoran's (2009) review of the literature on focus groups where they found that "Krueger (1994) has endorsed the use of very small focus groups, what he terms 'mini-focus groups' (p. 17), which include 3 (Morgan, 1997) or 4 (Krueger, 1994) participants, when participants have specialized knowledge and/or experiences to discuss in the group" (p. 3).

Woodford Focus Group participants $(n=23)$ were drawn from festival goers in 2009. The age range was 18 to 65 with the majority in the 31 to 55 year age bracket. Gender distribution was relatively even (52\% female and $48 \%$ male). The majority of participants (96\%) were campers at the Festival site and hence, this figure may indicate some form of self-selection. Most participants (95\%) came from over one hour's drive away with $32 \%$ from interstate (New South Wales and Tasmania). Most were well educated with $65 \%$ having completed a University degree (one had only completed Primary School). A strong "intention to return" was expressed $(92 \%)$. Similar findings were evident in earlier research $(N=2,522)$ conducted by the Queensland Folk Federation (QFF, 2008). The sample was considered to be representative of the festival population and therefore appropriate for data analysis.

The National Country Music focus group participants $(n=5)$ were drawn from attendees of the 2008 Muster who lived in and around Nambour.
The age range was 31 to 65 with the majority in the 55 to 65 year age bracket. Gender distribution was relatively evenly split ( $60 \%$ female and $40 \%$ male). Again, all participants were campers who were located over 1 hour's drive away (as expected given the method of recruitment). Most were well educated with $60 \%$ having completed a University degree and all $(100 \%)$ having completed secondary schooling. All participants had attended three or more festivals and could therefore be described as "regular attenders." A strong "intention to return" expressed by all participants tended to align with their self selection as members of the focus group. The sample showed a similar profile to that of previous research by the National Country Music Muster in 2008. Although participants were drawn from only one region and were from a slightly older age range to the general festival population (National Country Music Muster, 2008), the sample was deemed to be appropriate for data analysis.

In the focus groups, questions were posed about perceptions of the Festival and how participants related to the event and the place, their festival consumption patterns and their sense of self within the festivalscape. Questions sought viewpoints about the meaning of place within the festival, favourite places, and tangible elements. While questions were deliberately general to maximize the potential range of emerging themes, a probing discussion ensured that rich data was gathered on issues pertaining to the blended festivalscape and ways in which the TBL elements of people, place, and profit could be overlaid to the consumer perspectives of the festivalscape.

Only one participant was a "first-timer" with all others being "repeat customers" who had attended three or more festivals. All participants entered into a lively discussion about their festival experiences and personal perceptions. Results of the focus groups and in-depth interviews with festival managers were collated into major themes (Greenbaum, 1998) to report on the dominant findings. Key findings from the focus groups and management indepth interviews were drawn together under the three TBL themes of People (social factors), Place (environmental factors), and Profit (economic factors) as they relate to the blended festivalscape and in turn, the sustainable management of the festival.

The results of the study are now discussed. Par- 
ticipants' actual names have been substituted for confidentiality in our reporting.

\section{Findings}

\section{Theme 1: People and the Blended Festivalscape}

The "people and blended festivalscape" theme aligns with the social aspect of the TBL framework of interest in this study. Findings from the Phase 1 management interviews showed that managers of both festivals were highly focused on their visitors' needs and creating and maintaining a festivalscape aligned with their expectations in terms of comfort, desirability, and authenticity. Expectations of authenticity are often realized by the use of staged authenticity (McCannell, 1973) where the actual authenticity of the festivalscape is not as important as the creation of a customized authenticity where staging does not necessarily equate with superficiality in the consumer's mind (Chhabra, Healy, \& Sills, 2003; Wang, 2007). In the context of a blended festivalscape, the notion of "authenticity" needs to be viewed through the eyes of the festival-goer, as developed over time, who has the power to accept or reject the legitimacy of the components of the servicescape within its natural setting. Indeed, festival-goers take on a positive role in the creation of a festivalscape that reinforces their self-image. While seeking a genuine, unadulterated, or authentic experience (Theobold 1998), they also seek the provision of basic modern services such as toilets and shower blocks. Festival consumers are happy to accept some of the comforts of home in their natural bush setting that do not compromise the perceived authenticity of their experience. Managers within both festivals seek to ensure that incremental improvements are made to the blended festivalscape without endangering the very nature of the "authentic" experience being sought by festival-goers. They perceive themselves as holders of the trust that maintains the festival vision that is largely embodied by their blended festivalscapes. The success of this sustainable management goal was evident in comments made by focus group participants:

It's the situation where people are going to the bush, they can camp with their mates, enjoy one another's company in a relaxed atmosphere. That's been the success of the Muster, even though you can go to any other festivals and see the same lineup of acts. It's just where we hold it that has kept us going for all these years. (FG1, Muster)

The creation of something that is familiar, yet still an adventure for attendees, is the key to Woodford Folk Festival where a number of venues and meeting places are adjusted each year. Comments made by festival attendees reflect both the potential impact of these changes and the risk of an overgentrification of the site that could stifle the conditions that bind festival-goers together in a shared experience:

Well, for me, I suppose I know between Woodfords', or between festivals, this site, a lot of the structures that we see here, don't exist. But for this special time every year it's all assembled and it's made into a magical village that's familiar to anyone who's been here more than once. (FG2, Woodford)

I think what they've created here-I mean it's been a long time in the making-I don't think it would be easy to create this - It's the whole sense of community that happens here and I think some of the extremes (of weather and subsequent site conditions), although they can drive us all crazyit's what brings people together. (FG3, Woodford)

The potential dangers in making incremental changes or over-balancing were also highlighted:

It's gotten very slick ... getting dangerously close to getting too slick, polished, and professional. (FG1, Woodford)

Attendees at both festivals expressed a desire to engage with the natural environment aspects of the blended festivalscape. Those attending Woodford focused on the 'spiritual significance of the hills and trees' (FG2, Woodford), while those at the Muster concentrated more on the perspective that:

It's got a real country feel to it. And I think part of that is being isolated like it is and everyone wandering around. Of course they're wearing the hats and all the gear. It's got that real country feel to it .... it's the Bush. (FG1, Muster)

Keeping the festival aligned with the "bush" was critical to the appeal of the Muster for participants as it captures the essence of the experience being 
sought. The "bush" is not just the natural environment but about how humans relate and live within it. The "bushy" living off the land is an iconic image of early Australia and is often juxtaposed alongside the "city-dweller" stereotype. The person who loves the country/bush is also seen as someone who, while respecting nature, is willing to shape it to their own needs.

Each year when people come to the event, it looks a bit different. So that each venue is done with a specific theme. So that people come year after year, there's something fresh, there's something different that wasn't there last year ... all those facades in keeping with the bush atmosphere.... so it might just be old junk from the dump or whatever that builds those facades up, but plenty of color. It's all a happy atmosphere. (FG1, Muster)

At both festivals, camping in the blended festivalscape was seen to be very important to the experience as a whole. At the Muster, this component formed part of the mythology of the "Australian Bush" experience, with its well planned adventure aspects, while at Woodford the camping component is embedded more in the traditions of the freedom seeking Woodstock music festival of the 1960s, with its more ad hoc, and sometimes back to nature approach to camping out and collectively engaging in celebration. Contributions of people to the blended festivalscape could also be readily identified in clothing choices of participants with "Asian and 1960s gear" featured at Woodford and a sea of "denim jeans and Akubra hats" adding to the festivalscape at the Muster. As observed by Xie (2003), "in authenticity is not inherent in the visitor experience but rather is a variable that depends upon the expectations and goals of the visitors" (p. 159).

Both festivalscapes allow for self-determination of what parts of the festivalscape the consumers engage with, as exemplified by these two participants:

You'd turn a corner, something different. Turn another corner, something different. And that is still here and that is really a great, wonderful thing about it. Because if you decide this end is no good, I want to go somewhere else, you can go. (FG4, Woodford)

You just go in there and do your thing and go from venue to venue. (FG1, Muster)

\section{Theme 2: Place and the Blended Festivalscape}

This second theme, "place and blended festivalscapes," aligns with the environmental aspect of the TBL framework. Work on the Woodford site commenced in September 1994. Data gleaned from the in-depth interviews showed that festival organizers have incrementally improved the site each year to cater for increasing audience numbers and to deliver a higher level of festival-goers comfort, introduce environmental initiatives, comply with statutory legislation, and upgrade existing facilities in a financially sustainable way. Woodford set out to implement strategies that involved maintaining existing valuable natural assets and re-establishing ecosystems that had been degraded through years of use of the site as a dairy farm. It has sought to provide a user-friendly place of natural beauty in which festival-goers meet and share the arts, humanities, and folklore.

Our main thing has been to keep improving the infrastructure on the site. Not by building more buildings but through basics like the roadways, amenities and toilets, and growing trees so that in heat there's shade. And that makes a huge difference - a tree to sit under or camp under. A massive difference. So that's where we've been putting our investment. (Woodford Management)

According to festival managers, each time a decision is made to change the Woodford site and/or establish new infrastructure, a TBL approach is taken to assess its viability and desirability. "Consideration is given to triple bottom line through committee meetings and liaising with the government/community bodies affected by the event" (Muster Management) and at Woodford, specific "environmental, social, and economic" planning and reporting mechanisms are in place. An example of this was seen in 2007 when the need to remove a number of trees to facilitate new camping grounds incorporated careful environmental impact studies to minimize damage to indigenous plants and wildlife through a replanting project that produced a net environmental benefit for the site. The reasoning behind this initiative was fully explained at a "public forum" at the next festival to ensure ongoing stakeholder support.

The Muster site at Amamoor (a short distance from the closest regional town of Gympie) is owned 
by the Queensland Forestry Department. An arrangement has been made so that this State land can be used for the Muster. Work on the site commenced in September 1985 with car parking, planned camping facilities, showers and toilets, and a central entertainment precinct being established to form the built festivalscape. The natural festivalscape takes visitors over streams and through rolling hills to a "bush camping" environment.

As the festival does not own the site any major changes must be approved by the government owners and are subject to strict environmental guidelines. Incremental improvements to the built environment, for example parking, have sought to create a more pleasant experience for the festivalgoers each year.

People come year after year, there's something fresh, there's something different that wasn't there last year. Even though it might be the same marquee, it's got a different façade on the front or it might be the same façade for a couple of years, but the one beside it might be different. Or we might change that venue from doing that, to doing something else. And it's just-I think façade is the right word - but the actual foyer will change. (Muster Management)

The Muster has also invested significantly in camping facilities to balance the needs of a more comfort oriented visitor with the "bush" rustic charm of the setting. A stated aim is to "maintain the national park (Muster site) as a natural environment with as few societal changes as possible." In this regard, festival-goers form an active part of the servicescape design with the establishment of a strong tradition of "dressing" individual campsites, sometimes to a very elaborate degree.

Love the camping site. even if you're camped there with 60,000 of your closest friends, it still feels like a day in the bush. You can sit there and listen to the birds. And since I had my motorbike accident I can't do day and night, so I usually hang around the camp during the day and then I'll do the night. And yeah, it's really peaceful. (FG1, Muster)

To some extent the phenomenon can be seen as being similar to that of Christmas Street lights where neighborhood houses all participate and the pressure builds to be more creative each year. As pressure mounts on space the issue of the number of camping sites and their size is going to become more problematic in designing the site. As a management representative of Muster management acknowledged:

We're really running out of area for people to camp - whether it be one night or two nights. So we've got to become ... a lot more efficient in he use of our land for camping. Where we've been fairly generous with people camping, I think we've got to be probably a little bit more regimented in the future. It's a hard balancing act between being regimented and leaving the atmosphere as you want it.

The Woodford commitment to enhance the festival "place" entails active intervention in the environment of the site rather than just passive caring towards what is present. This involves visible "front stage" interventions such as the planting of 80,000 trees to provide shade and atmosphere while reestablishing natural ecosystems, as well as "back stage" interventions of recycling and other sustainable practices.

The ability to sculpt the festivalscape to achieve TBL outcomes is a key advantage that Woodford Folk Festival has in addressing the future development of their site. Roads are changed and venues altered and relocated each year with both reactive and proactive strategies used to create a sense of communities where practicality meets fantasy in a hedonistic service setting. A Woodford management representative stated that:

it's the festival atmosphere that stands out as the reason why people are motivated to attend ... we want Woodford to be a community, not an institution.

Findings from the focus group participants suggest that the sustainability strategies of restoring, enhancing, and sculpting the natural environment are being well received by consumers.

I don't find the impact of the structure of the festival to be that really out of place ... it seems to fit into the environment reasonably well. (FG4, Woodford)

Woodford management is strongly aware of the environmental commitment of their loyal support 
base and the need to maintain communications with them on issues that may impact on the natural environment of the site. They actively communicate their strategies for meeting the environmental challenges on the festival site by minimizing negative impacts of activities such as rubbish disposal and the proactive affirmation of the environment through initiatives such as their annual tree planting weekend "The Planting." The active demonstration of management's commitment to the environment that goes beyond the regulatory necessities enhances the brand reputation of this festival and consumer loyalty.

Being located in a state forest means that the $\mathrm{Na}-$ tional Country Music Muster is limited in its ability to sculpt its natural environment outside of the footprint sanctioned by the State Government. In many ways this limitation of freedom enhances the "authenticity" of the festivalscape in the eyes of the target market:

Everyone takes the Mickey out of the bush you know. But being out in the bush is just so, so relaxing. (FG1 male, Muster).

I think it is that switch-off too. Like, when you get there, like you say it's separate from the town, that's .... you don't have to think about it. Whatever you do, you don't have to think about it because you've actually crossed that line. You've left the town. (FG1 female, Muster)

I actually love that you get both sides of it. You get that real kick-back - but phones do work out there these days because they've got the antennae up. But sometimes once you're out there, there's no phones, you don't have to be responding. But then on the other hand you've got that whole carnival kind of thing. (FG1 female, Muster)

The importance of the synergy created by the Muster blended festivalscape was best summed up by its management:

In our surveys - there is one word that always comes up top on there-and that is the atmosphere. It's not Leigh Kernigan, it's not John Williamson and whatever. And I think it comes back to atmosphere. We had a huge debate when we decided to go away from the Webb Brothers property at Widgee, which was on a big cattle station, and go to the state forest. There was a whole division saying "it won't work, cos you're going from where it started to this whole new site." None of us were Einstein's, but it doubled in size in the next year when we changed. I'm still convinced that it would never have worked if we went to the local showgrounds.

The blended festivalscape is critical to the atmospherics of the Muster and the balance between the built and natural environment, man and the bush, plays a pivotal role in the attractiveness of the event and its corresponding financial success.

It's the situation where people are going to the bush, they can camp with their mates, enjoy one another's company in a relaxed atmosphere. That's been the success of the Muster, even though you can go to any other festivals and see the same lineup of acts. (Muster Management)

Investment in infrastructure that is sympathetic to the natural environment, and its government owners, has ensured its sustainability over an extended period of time, some 25 years, while many other festivals have failed. A primary objective of the Muster management, both by choice and regulatory necessity, has been to minimize the inevitable negative impacts on the environment caused by the usage of the site each year. These impacts include such considerations as damage to flora and fauna, water and land contamination, and the like (Jones, 2010). The planning of the Muster blended festivalscape clearly demonstrates a practical approach to use of the TBL framework that is aimed at ensuring a sustainable future for this event.

\section{Theme 3: Profit and the Blended Festivalscape}

Theme 3 examines profit and the blended festivalscape and aligns with the economic aspect of the TBL framework. The commercial aspects of the blended festivalscapes were widely recognized as necessities by most focus group participants.

You know, part of the appeal for me it's all the local little schools that have their food stalls and their ice sellers-I love that-I would never want that to change. (FG1, Muster).

when you think about the value of the ticket, your camping grounds - your entertainment - it's cheap. (FG3, Woodford).

While they enjoyed the natural settings, participants also appreciated the costs involved in the 
staging of events and providing essential services. While some expressed concern about rising ticket prices (particularly those at the Muster), the majority recognized the value for money aspects of the festivalscape. Managers at both festivals acknowledged the importance of retaining a blended service escape (natural and built) that meets the expectations of their customers if they are to continue to operate profitably.

\section{Discussion}

Petrick and Lee (2006) note that the past few decades have established festivals and events as one of the fastest growing sectors in the world leisure industry. A growing market is therefore likely for regional festivals which succeed in delivering desirable hedonic experiences (Gelder \& Robinson, 2009; Hightower et al., 2002; Joseph-Mathews, Bonn, \& Snepenger, 2009; Moscardo, 2008; Richards \& Wilson, 2006).

This research recognizes the growing importance of nonurban festivals in a tourism context and the absence of research into the understanding of blended festivalscapes It further recognizes the potential for utilizing TBL as a planning framework to achieve positive results for both festival managers and consumers without compromising wider community expectations about preserving the natural environment.

\section{Blended Festivalscapes}

There was an overwhelming awareness among all research participants, both festival consumers and managers from the two festivals, that a key ingredient in the successful staging of the event was the maintenance of balance within the blended festivalscape. As the ocean did in Kwortnik's (2008) study of cruise ships, the natural contours of the land, the bush, the smell, and scents of the natural environment blend with the man-made and social constructs to form these two blended festivalscapes. The findings show that the sustainability of festivals is intrinsically linked to the incorporation of all three TBL areas in planning a blended festivalscape, these being people, place, and profit dimensions. The balancing of these dimensions will always be contentious as different agendas and interpretations are brought into play by the various stakeholders. Here, a closer examination of tools and further refinements to the sustainability management practices of festival organizers may be desirable to respond to consumer perspectives about the blended festivalscape.

\section{People}

Festivalscapes provide meeting places for hedonic service encounters (Hightower et al., 2002; Quinn, 2005). Festival management decisions surrounding the development of the festivalscapes were shown in this article to be acutely attuned to people elements in planning the respective sites. In simplest terms they could be termed as "customer focused," but the relationship goes beyond this and is reliant on a bond or trust that is formed between the management, the festival consumers, the entertainers, and other service personnel. This bond, or sense of communitas, means that not only do festival consumers perceive themselves as an audience but also actors on the same stage where they seek an authentic expression of self (Wang, 1999) through the event. In constructing their festivalscapes, both management teams were clearly focused on satisfying the needs of festival-goers with facilities and services that enhance the festival experience, but still provide environmentally and economically sustainable outcomes. Focus group participants from both festivals strongly expressed their need to enhance the feeling of community in planning the blended festivalscape.

\section{Place}

The importance of place could be seen from a number of perspectives. While both festivals demonstrated their ability to move to another geographic location, consumer expectations of proximity to market, aesthetics, and cultural congruence (e.g., engagement with "the bush" (Arnould, Price, \& Tierney, 1998) were key place components. Place was also seen as blending the natural, man-made, and social environments.

Finally, place was seen as a staged setting providing basic services, established traditions such as venues and camping grounds and providing new adventures. Managers of both festivals recognized the need for incremental improvements to facilities, services, and aesthetics without compromising the 
festival's perceived authenticity among consumers (Joseph-Mathews et al., 2009; Petrick \& Li, 2006). The stability of both festivals, both in excess of 20 years, demonstrates that their incremental approach to site development has been successful from both financial and stakeholder dimensions (Getz, 2009).

\section{Profit}

Managers within both festivals were careful to focus on the financial stability of their events. Woodford, who owns their site, has concentrated on continuing to develop the festivalscape infrastructure in a manner that provides for good environmental and social outcomes, while at the same time producing long-term financial benefits/savings (e.g., their move to on-site sewerage treatment works). Conversely, the Muster, which does not own the site, does not actively seek to return profits into site infrastructure but rather seeks to enhance the temporary atmospherics of the festivalscape and distribute its profits to charities. Both festival management teams have clearly identified their return on investment based on a not-for-profit charter, rather than a shareholder profit model (Getz, 2007). Festival consumers interviewed, while not always happy about the cost of attending, uniformly recognized the value for money proposition of the festivals. One reason for their willingness to pay the admission price was their wish to contribute to the cause of their festival.

\section{TBL Framework}

The application of theory to the two case studies examined, Woodford Folk Festival and the National Country Music Muster, demonstrates that Triple Bottom Line theory (Elkington, 1997; Fredline et al., 2005; Getz, 2009; Hede, 2008) may offer a viable framework for the planning blended festivalscapes.

While there were differing interpretations of TBL principles across the managers of the two festivals depending on their ownership of the site or physical festivalscape, both recognized the importance of integrating a more holistic concept or a blended festivalscape into their planning and reporting activities. The focus group participants from both festivals recognized the relevance of TBL, even though they did not use this terminology in communicating their thoughts and ideas about the blended festivalscape.

\section{Conclusion}

This article has reported on an initial exploration that is a preliminary step towards the creation of a TBL planning and evaluation model in the context of blended festivalscapes. Limitations of the work are its confinement to two Australian case studies, the Woodford Folk Festival and the National Country Music Festival, and relatively small samples of participants. Multiple case studies and larger samples that include a wider range of festivals could further inform the body of knowledge about festivalscapes and related sustainability planning.

Place was seen in both case studies, and by all participants, as a blending of the natural, man-made, and social environments: what we have termed the blended festivalscape. Accordingly, our constructed definition of the blended festivalscape arising from the study is: a place in which all experienced elements of the festivalscape sit collectively and comfortably with each other and recognize each other's relevance and importance. This aligns with Clarke and Schmidt's (1995) concept of a "symbiotic relationship."

Observations from this research have demonstrated that the TBL framework can serve as a lens through which the elements of the blended festivalscape can be individually and holistically investigated among stakeholders (Hede, 2008) to ascertain how to maximize benefits and minimize negative impacts. The findings of this study support the position of Cherubini and Lasevoli (2006) that "the 'SEE' (TBL) methodology can be used before or after the event in order to develop a real knowledge event management able to assist the decision maker in his evaluations process" (p. 14). The major challenge for future researchers in this area will be to move beyond the theoretical concept of a blended festivalscape to develop and refine practical planning and evaluation methodologies to optimize its sustainability. The authors plan to reflect further on the findings of this study in reporting on a more extensive study of blended festivalscapes to inform and assist event organisers.

\section{References}

Aaker, D., Kumar, V., Day, G., Lawley, M., \& Stewart, D. (2007). Marketing research: The second Pacific Rim edition. Milton, Queensland: John Wiley and Sons Australia. 
Aldrich, R. (1966). The development of '-scape'. American Speech, 41(2), 155-157.

Arnould, E., \& Price, L. (1993). River magic: Extraordinary experience and the extended service encounter. Journal of Consumer Research, 20(1), 24-35.

Arnould, E., Price, L., \& Tierney, P. (1998). Communicative staging of the wilderness servicescape. The Services Journal, 18(3), 90-115.

Beeton, S. (2004). Rural tourism in Australia-Has the gaze altered? Tracking rural images through film and tourism promotion. International Journal of Tourism Research, 6(3), 125-135.

Belk, R. (1975). Situational variables and consumer behaviour. Journal of Consumer Behaviour, 2(3), 157-164

Bennett, D. J., \& Bennett, J. D. (1970). Making the scene. In G. Stone \& H. Farberman (Eds.), Social psychology through symbolic interactionism (pp. 190-196). Waltham, MA: Ginn- Blaisdell.

Berman, B., \& Evans, J. (1995). Journal of retail management: A strategic approach (6th ed.). Englewood Cliffs, NJ: Prentice-Hall.

Bitner, M-J. (1992). Servicescapes: The impact of physical surroundings on customers and employees. Journal of Marketing, 56(2), 57-71.

Bonn, M., Joseph-Mathews, S., Dai, M., Hayes, S., \& Cave, J. (2007). Heritage/cultural attraction atmospherics: Creating the right environment for the heritage/cultural visitor. Journal of Travel Research, 45(3), 345-354.

Bowen, H., \& Daniels, M. (2004). Does the music matter? Motivations for attending a music festival. Event Management, 7(3), 155-164.

British Petroleum (1987). BP and sustainability. Retrieved from http://www.bp.com/sectiongenericarticle.do?cate goryId $=2312 \&$ content $I d=7061112$

Brown, S., \& Sherry, J. (Eds.) (2003). Time, space and the market: Retrospect rising. New York: M.E. Sharpe.

Carson, D., Gilmore, A., Perry, C., \& Gronhaug, K. (2001). Qualitative market research. London: Sage Publications.

Chhabra, D., Healy, R., \& Sills, E. (2003). Staged authenticity and heritage tourism. Annals of Tourism Research, 30(3), 702-719.

Cherubini, S., \& Lasevoli, G. (2006, January). Stakeholders event evaluation: Notte Bianca case study. Paper presented at Le Tendenze Del Marketing In Europa (Marketing Trends in Europe), Venice.

Clarke, I., \& Schmidt, R. (1995). Beyond the servicescape, the experience of place. Journal of Retailing and Consumer Services, 2(3), 149-162.

Cochrane, J. (2009). Changing landscapes and rural tourism. In R. Thomas (Ed.), Managing rural tourism: A case study of Yorkshire, England (pp. 65-77). Ilkley: Great Northern Books.

Creswell, J. (2003). Research design: Qualitative, quantitative and mixed methods approaches (2nd ed.). California: Sage Publications.

Curtin, S. (2010). The self-presentation and self-development of serious wildlife tourists. International Journal of Tourism Research, 12(1), 17-33.
Donovan, R. J., \& Rossiter, J.R. (1982). Store atmosphere: An environmental psychology approach. Journal of Retailing, 58(1), 34-57.

Dredge, D., \& Whitford, M. (2010). Policy for sustainable and responsible festivals and events: Institutionalization of a new paradigm - a response. Journal of Policy Research in Tourism, Leisure and Events, 2(1), 1-13.

Elkington, J. (1997). Cannibals with forks: The triple bottom line of 21st century business. Oxford: Capstone.

Ezeh, C., \& Harris, L. (2007). Servicescape research: A review and a research agenda. The Marketing Review, 7(1), 59-78.

Fern, E. (1982). Why do focus groups work: A review and integration of small group process theories. In A. Mitchell \& A. Arbor (Eds.), Advances in consumer research (Vol. 9, pp. 444-451). Duluth: Association for Consumer Research.

Fredline, E., Raybould, R., Jago, L., \& Deery, M. (2005). Triple bottom line event evaluation: A proposed framework for holistic event evaluation. Paper presented at the International Event Research Conference, Sydney.

Fullerton, M. (1928). The Australian bush. London: J.M. Dent and Sons.

Gelder, G., \& Robinson, P. (2009). A critical comparative study of visitor motivations for attending music festivals: a case study of Glastonbury and V Festival. Event Management, 13(3), 181-196.

Getz, D. (2000). Explore wine tourism: Management, development \& destinations. New York: Cognizant Communications Corporation.

Getz, D. (2007). Event studies: Theory, research and policy for planned events. Oxford: Butterworth-Heinemann.

Getz, D. (2009). Policy for sustainable and responsible festivals and events: Institutionalization of a new paradigm. Journal of Policy Research in Tourism, Leisure and Events, 1(1), 61-78.

Gibson, C., \& Stewart, S. (2009). Reinventing rural places: The extent and impact of festivals in rural and regional Australia. Canberra: Australian Research Council.

Greenbaum, T. (1998). The handbook for focus group research (2nd ed). London: Sage Publications.

Hair, J., Bush, R., \& Ortinau, D. (2003). Marketing research. Sydney: McGraw Hill Education.

Hede, A-M. (2008). Managing special events in the new era of the triple bottom line. Event Management, 11(1-2), $13-22$.

Hightower, R., Brady, M., \& Baker, T. (2002). Investigating the role of the physical environment in hedonistic service consumption: An exploratory study of sporting event. Journal of Business Research, 55(9), 697-707.

Holahan, C. (1982). Environmental psychology. New York: Random House.

Hubbard, G. (2009). Measuring organizational performance: Beyond the triple bottom line. Business Strategy and the Environment, 18(3), 177-191.

Jones, M. (2010). Sustainable event management. London: Earthscan.

Joseph-Mathews, S., Bonn, M., \& Snepenger, D. (2009). At- 
mospherics and consumers symbolic interpretations of hedonic services. International Journal of Culture, Tourism and Hospitality Research, 3(3), 193-210.

Kim, H., \& Jamal, T. (2007). Touristic quest for existential authenticity. Annals of Tourism Research, 34(1), 181201.

Kotler, P. (1973). Atmospherics as a marketing tool. Journal of Retailing, 49(4), 48-64.

Kwortnik, R. J., (2008). Shipscape influence on the leisure cruise experience. International Journal of Culture, Tourism and Hospitality Research, 2(4), 289-311.

Lee, Y. K., Lee, C. K., Lee, S. K., \& Babin, B. J. (2008). Festivalscapes and patrons' emotions, satisfaction, and loyalty. Journal of Business Research, 61(1), 56-64.

Lin, I. Y. (2004). Evaluating a servicescape: The effect of cognition and emotion. International Journal of Hospitality Management, 23(2), 163-178.

Mattila, A., \& Enz, C. (2002). The role of emotions in service encounters. Journal of Service Research, 4(4), 268 277.

MacCannell, D. (1973). Staged authenticity: The arrangement of social space in tourist settings. American Journal of Sociology, 79(3), 589-603.

Mc $\overline{\text { Donnell, A., \& Hall, CM. (2008) }}$. A framework for the evaluation of winery servicescapes: A New Zealand case. PASOS, 6(2), 231-247.

Mehrabian, A., \& Russell, J. (1974). An approach to environmental psychology. Cambridge: MIT Press.

Milne, M. J., Kearins, K., \& Walton, WS. (2006). Creating adventures in wonderland: The journey metaphor and environmental sustainability. Organisation, 13(6), 801839.

Morgan, D. L. (1997). Focus groups as qualitative research (2nd ed). Thousand Oaks: Sage Publications.

Morgan, M. (2008). What makes a good festival?: Understanding the event experience. Event Management, 12(2), 81-93.

Moscardo, G. (2008). Analysing the role of festivals and events in regional development. Event Management, 11(1-2), 23-32.

Muller, H. (1994). The thorny path to sustainable development. Journal of Sustainable Tourism, 2(3), 131-136.

Newman, A. J. (2007). Uncovering dimensionality in the servicescape: Towards legibility. The Services Industries Journal, 27(1), 15-28.

Norman, W., \& MacDonald, C. (2004). Getting to the bottom of 'triple bottom line'. Business Ethics Quarterly, 14(2), 243-262.

Oakes, M. (2006). The tourist landscape paradox. Social and Cultural Geography, 8(3), 433-453.

Onwuegbuzie, A., Dickinson, W., Leech, N., \& Zoran, A. (2009). A qualitative framework for collecting and analyzing data in focus group research. International Journal of Qualitative Methods, 8(3), 1-21.

Parasuraman, A., Zeithaml, V., \& Berry, L. (1985). A conceptual model of service quality and its implications for future research. Journal of Marketing, 49, 41-50.

Petrick, J., \& Li, X. (2006). A review of festival and event motivation studies. Event Management, 9(4), 239-245.
Queensland Folk Federation. (2008). Woodford visitor survey report 2007/2008. Woodford: Queensland Folk Federation.

Quinn, B. (2005). Changing festival places: Insights from Galway. Social and Cultural Geography, 6(2), 237-252.

Relph, E. (1976). Place and placelessness. London: Pion.

Richards, G., \& Wilson, W. (2006). Developing creativity in tourist experiences: A solution to the serial reproduction of culture? Tourism Management, 27(6), 1209-1223.

Robertson, M., Rogers, P., \& Leask, A. (2009). Progressing socio-cultural impact evaluation for festivals. Journal of Policy Research in Tourism, Leisure and Events, 1(2), 156-169.

Rogers, M., \& Ryan, R. (2001). The triple bottom line for sustainable community development. Local Environment, 6(3), 279-289.

Rosenbaum, M. (2006). Exploring the social supportive role of third place in consumer's lives. Journal of Service Research, 9(1), 59-72.

Sherwood, P. (2007). A triple bottom line evaluation of the impact of special events: The development of indicators. Unpublished doctoral dissertation, Victoria University, Centre for Hospitality and Tourism Research.

Shostack, G.L. (1977). Breaking free from product marketing. Journal of Marketing, 41(2), 73-80.

Slatten, T., Mehmetoglu, M., Svensson, G., \& Svaeri, S. (2009). Atmospheric experiences that emotionally touch customers: A case study from a winter park. Managing Service Quality, 19(6), 721-746.

Small, K. (2007). Understanding the social impacts of festivals on communities. Unpublished doctoral dissertation, University of Western Sydney, Sydney.

Taylor, R., \& Shanka, T. (2002). Attributes for staging successful wine festivals. Event Management, 7(3), 165175.

Theobold, W. (1994). The context, meaning and scope of tourism. In W. Theobold (Ed.), Global tourism: The next decade (pp. 3-19). Oxford: Butterworth-Heinemann.

Thrane, C. (2002). Music quality, satisfaction and behavioural intentions within a jazz festival context. Event Management, 7(3), 143-150.

Timothy, D. J. (2000). Cross-border partnership in tourism management: International parks along the US-Canada Border. In B. Bramwell \& B. Lane (Eds.), Tourism collaboration and partnerships politics, practice and sustainability (pp. 20-43). Clevedon: Channel View Publications.

Tombs, A., \& McColl-Kennedy, J. (2003). Social-servicescape conceptual model. Marketing Theory, 3(4), 447475.

Tuan, Y. (1974). Topophilia, a study of environmental perception, attitudes and values. New Jersey: Prentice-Hall.

Tuan, Y. (1977). Space and place - the perspective of experience. Minneapolis: University of Minnesota Press.

Turner, V. W. (1974). Dramas, fields and metaphors. Cornell: Cornell University Press.

Ulrich, R. S. (1983). Aesthetic and affective responses to natural environment. In I. Altman \& J. F. Wohlwill (Eds.), Human behaviour and the environment, 6: Be- 
haviour and the natural environment (pp. 85-125). New York: Plenum.

Ulrich, R. S. (1986). Human responses to vegetation and landscapes. Landscape and Urban Planning, 13, 29-44.

Ulrich, R. S. (1993). Biophilia, biophobia, and natural landscapes. In S. R. Kellert \& E. O. Wilson (Eds.) The biophilia hypothesis (pp. 73-137). Washington: Island Press.

Wakefield, K. L., \& Blodgett, J. G. (1994). The importance of servicescapes in leisure service settings. Journal of Services Marketing, 8(3), 66-76.

Wang, N. (1999). Rethinking authenticity in tourism experience. Annals of Tourism Research, 26 (2), 349-370.
Wang, Y. (2007). Customized authenticity begins at home. Annals of Tourism Research, 34(3), 789-804.

World Commission on Environment and Development. (1987). Our common future. Retrieved from http://www. un-documents.net/ocf-02.htm\#I

Xie, P. (2003). Visitors' perceptions of authenticity at a rural heritage village: A case study. Event Management, 8(3), 151-160.

Yin, R. (1994). Case study research: Designs and methods. London: Sage.

Zikmund, W. (2003). Business research methods (7th ed). South-Western, USA: Thompson. 